\section{Thirty-third Annual Meeting}

The 33rd Annual Meeting of the College was held at the Harrogate International Conference Centre, Edinburgh from 6-9 July 2004.

\section{Business Meeting}

The Business Meeting of the Royal College of Psychiatrists was held on Thursday, 8 July 2004, and was chaired by the President, Dr Mike Shooter. It was attended by 70 members of the College.

The Minutes of the previous meeting held in Edinburgh on Wednesday, 2 July 2003, and published in the Psychiatric Bulletin, December 2003, were approved and signed.

\section{Report from the President}

The world has changed since the College received its charter in 1971. Although education is still an important part of its remit, the College is now a political animal. Gone are the days when we could sit back and expect the rest of the world to fit in with the view from 17 Belgrave Square. The price of Government support for mental health has been Government interference, and the College must engage in politics for the good of the profession, services and those in their care. Many are the strategies that have to be used in the process. Sometimes it feels like the Labours of Hercules!

Over the past year, the College has tackled some huge issues - Remit (what the proper scope of psychiatry should be when government want us to be agents of social order and the pharmaceutical industry want us to treat social unhappiness); Roles (how to re-establish traditional values of consultant working within new multi-disciplinary teams); Recruitment (how to devise a training scheme that will simultaneously attract recruits and produce consultants fit for patient needs); Restructuring (the overhaul of arthritic College processes); Reputation (our responsibilities to root out discrimination, clean up our interface with the drug companies, accept a role in the discipline of poorly performing doctors and support those colleagues in distress); and Relationships (the shift from alliance with government to alliance with the organisations representing fellow professionals, patients and their carers).

All psychiatric patients feel marginalised by stigma. Sometimes those who treat them feel marginalised within the medical profession. But there are some groups of people who feel at the margin of the margins - prisoners with mental illness and staff struggling to help them in awful conditions; Black and minority ethnic communities alienated from insensitive services; refugees and asylum seekers more punished than helped; 'looked after' children who are not looked after at all; sick doctors and those under investigation, pushed to the edge of their own careers; the homeless and deprived, victims everywhere. I am determined that we should not repeat the process in College policy by marginalising them in pursuit of the 'big' issues. And we should look to their needs proactively, not reactively in the wake of tragedies like those of Daksha Emson and David Rocky Bennet. The NHS is full of the sound of stable doors being shut after the horse has bolted!

The pace of all this change has been fast and furious. We have tried not to do to members what we have often accused the Government of doing - throwing change at us faster than we can 'own' and assimilate it. But changes are necessary lest we have change imposed upon us from the outside or be treated as an irrelevance in the modern mental health world. The changes accomplished so far are a tribute to those members who give of their time, often in the teeth of opposition from their employers, and the College staff who support us so wonderfully well.

Finally, the College should be warned of a growing disaffection among academic psychiatrists. By far the most unhappy people I have seen in my travels over the past year have been in academic departments struggling with the Research Assessment Exercise and feeling that the College no longer represents their interests effectively. There are those who wonder if they should break away from the College in some way. This would be a disaster. Clinical and academic psychiatry should be two complimentary parts of a whole. Clinical psychiatry should be based on research evidence. Research needs to be informed by clinical realities. It is essential to our College's future that this potential split be healed.

\section{World Psychiatric Association: Alleged Abuse of \\ Psychiatry in China}

Dr Mike Shooter reported that the resolution from the AGM in 2002 had gone to the WPA and it had been decided that an independent task force would ask permission of the Chinese Government to visit China to investigate allegations of abuse in psychiatry. However the Chinese Government had subsequently denied permission for the visit to proceed Council had received a report from the
WPA, which seemed to suggest that the allegations had been exaggerated, and that possibly some advice on psychiatric training in China was all that was required. Dr Shooter asked the meeting for views on how the College should proceed. Professor John Cox, Secretary General of the WPA, reported to the meeting that he hoped communications between the two organisations would improve in future. Debate indicated that the Membership was strongly supportive of a firm statement being made to the WPA and that support should be sought from the international psychiatric community for further action. Dr Shooter undertook to report the substance of the discussions back to Council for a decision as to future action.

\section{General business}

The formal Report of the Treasurer and a summarised version of the Annual Accounts for 2003 were received and approved. The reappointment of the auditors was approved. The new fees and subscription rates from 1 January 2005 were approved.

\section{Report from the Dean}

This is my first report to the Annual General Meeting, and the last year has been incredibly busy, uncertain and chaotic on the academic front.

During my first year as the Dean, I have been fortunate enough in having the help and support of a wonderful team of Associate Deans and staff at the Postgraduate Education Department at the College. We now have a full complement of Associate Deans who include Drs Anne Bird, Nick Brown, Joe Bouch and Kandiah Sivakumar. Anne Bird is responsible for examinations, and Joe Bouch for CPD. Nick Brown heads the Basic Training Specialist Advisory Committee, and Siva chairs the Specialist Training Committee. Nick Brown has been involved in developing the curriculum for Foundation Year 2, and has been taking the lead in the European Working Time Directive and Modernising Medical Careers overall. Various documents are in place, and will be published in forthcoming issues of the Psychiatric Bulletin. Dr Sivakumar has taken the lead in assessing applications for equivalence and for entry into the Specialist Register. Joe Bouch has been developing CPD for consultants, and Dr Bird has taken the lead in streamlining entry into examinations, especially for staff grade and associate specialists.

In the past year, for the first time, we have a Director of Flexible Training. Interestingly, this is a job shared between Drs Jane Marshall and Alicia Etchegoyen; the first time ever in any of the Royal Colleges 
that this has happened. Their main responsibilities are twofold; firstly to look at and streamline flexible training and all issues to do with it, and secondly to enable doctors to get back into the system following illness. In addition, we appointed Dr Nick Rose as Chair of the Overseas Doctors Training Committee, which is taking the lead in looking at equivalence.

\section{AFFILIATES, TRAINING AND ASSESSMENT}

In the past year we have put together a proposal for reviewing psychiatric training and assessment afresh. In view of impending changes following the establishment of PMETB, it has become crucial that we look at our training in the context of the European Working Time Directive. This has meant that the traditional models of MRCPsych courses and educational supervision have to change. Within the College there are several models which are being discussed. Although PMETB has been set up, there is still not clear guidance in terms of the direction the training is likely to take. It is supposed to come on-stream in October 2004. What is clear is that at some point soon, Article 14 will mean that entry to the specialist register will depend on clinical skills, experience and qualifications, whereas at present we can consider only qualifications and duration of training.

The most likely model to emerge would include merging of $\mathrm{SHO} / \mathrm{SpR}$ training: perhaps shifting the MRCPsych examination to a later date. However, the most innovative aspect of the assessment would be introduction of modular assessments as well as workplace assessments, which will contribute towards the MRCPsych qualification. In addition, my fantasy is to have the teaching materials on the web and part of exams on the web. Over the past year, the competencybased curriculum for specialist registrars has undergone further revision and is available on the College website. Work on the F2 curriculum is well advanced and it is hoped to have the curriculum for psychiatric SHOs drafted later this year. We have started work on modules for CPD for consultants, to be made available on the web.

In the first year of my Deanship, I have been able to link up very closely with the Regional Postgraduate Dean and work out strategies for the piloting of foundation year posts as well as the training of future consultants. I would like to take this opportunity to thank all the Associate Deans as well as Dr Gareth Holsgrove, Head of Postgraduate Educational Services and his staff, in particular Cate Cole, Lena Hartley, Joanna Carroll and Claire Drummond.

The challenges for the next year include sorting out the foundation year placements and the curricula, and starting to fine-tune assessment and training processes. If anything, it promises to be even busier and more eventful than the past year.

\section{Report from the Editor - Professor PeterTyrer}

The British Journal of Psychiatry and its associated publications has had a year of consolidation and steady advance. The BJP has continued to publish papers of high quality and its impact factor has risen to 4421. The Psychiatric Bulletin and Advances in Psychiatric Treatment also continued their popular progress and are well received by readers. The book programme under the Gaskell imprint has also made steady advance, with 11 published in the last year.

Despite this background, medical publishing is moving into choppy seas, with uncertainty pervading all our activities. The introduction of open access journals and the widespread use of the Internet for accessing published information has made it extremely difficult to make confident projections about the future. the subscription rates to almost all journals are falling and we have had approximately a $5 \%$ reduction to all our journals in the past 12 months. There has also been a reduction in advertising, mainly because of the relatively low rate of introduction of new drugs, and so our advertising revenue has fallen. the consequence of this is that the accounts show a small loss from the publications department of $f 68000$ over the last year, although this loss was set against the considerable overheads that the publications receive and the free distribution of journals to all members. However, the expectation is for the next few years that the core publishing activities of the Royal College will be unlikely to yield much in the way of significant profit.

However, there are opportunities on the horizon. The BJP will very shortly move over to online submission of manuscripts and reviews and in the long term should prove to be more cost-effective. We are also launching our online CPD journal in the spring of 2005, under the energetic editorship of Cornelius Katona, and are optimistic that this will be not only of great value to our members but should attract educational interest from many others, including the emerging countries of the European Union, and this will be of both intellectual and financial benefit to the College. The continued excellent stewardship of the Publications Department from Dave Jago and Andrew Morris, together with their harmonious team of assistants, remains a firm basis for advance, and their ability to operate effectively from an office that looks to cover the dimensions of Dr Who's telephone box from the outside but which accommodates it all nicely from the inside, continues to amaze.
Report from the Librarian Dr David Tait

I am pleased to report that the longawaited document, Key Resources for Psychiatric Libraries, has now been completed and will shortly be published on the College website. This has been with the help of the Virtual Library Committee with faculty, trainee and trainer representation, but should be seen very much as our first attempt. There will be an e-mail link back to the Library and Information Service and I would urge all members to contact us as when they have suggestions for new books, journals or electronic resources, or suggestions for removal of out of date or unsatisfactory material. The Virtual Library Committee will remain in existence and will be our reference point to evaluate suggestions. In addition, we shall formally review the document in 2 years' time.

I would like to pay tribute to Margaret Harcourt Williams, Archivist, who retired in June following 17 years of service to the College. Margaret has left the historical archive in excellent order, and her records management system will ensure that the College's activities, particularly with devolution to the English regions, continue to be archived appropriately.

At the time of reporting to the AGM, I advised of our Library and Information Services Officer, Morwenna Rogers, being on maternity leave and having just had her baby daughter. By the time this report is printed in the Psychiatric Bulletin our locum LIS Officer, Trudy Bruess, will be nearing the end of her maternity-leave cover for us and I wish to thank her for doing such an excellent job.

\section{Report from the Registrar - \\ DrAndrew Fairbairn}

Appointment of Deputy Registrar

Dr Muhammad Afzal Javed was appointed (2nd) Deputy Registrar (with special responsibility for non-career grade doctors, and SCPC) following advertisement and interview, and took office in April.

\section{Review of Bye-Laws and Regulations - amendments agreed by the AGM in 2003}

Approval has now been received from the Privy Council for the proposed BL amendments submitted to the AGM in 2003. Key amendments are:

Introduction of a category of International Associate, which will enable psychiatrists practising overseas who do not hold the MRCPsych qualification to enjoy closer links with the College (including participation in College meetings, receiving College journals, participation in the CPD programme and other educational activities). This will also enable the 
7?

columns
College to develop further its international profile.

Introduction of six International Divisions (largely based on the six WHO Regions) in place of Overseas Groups. Membership of the International Divisions will be automatic, according to country of residence or work.

Recognition of the registered titles 'MRCPsych' and 'FRCPsych' as a privilege of Membership and Fellowship (The titles were registered as trademarks in 2002.) The bye-line change means that the College can now withdraw the privilege of use of these titles from Members of Fellows whose subscriptions are more than 12 months in arrears (arrears to be paid before privileges are restored).

- The Court of Electors has the discretion to grant a licence to Members or Fellows whose subscriptions are in arrears to continue to use the Registered Titles MRCPsych and FRCPsych.

- Loss of this privilege does not preclude Members or Fellows from referring to having passed the MRCPsych Examination.

The ceiling on the number of Affiliates who can be registered in any year and the total number has been removed.

\section{FACULTIES AND SECTIONS}

Council agreed this year (as part of its discussion relating to the Daksha Emson Inquiry) to establish a new Section of Perinatal Psychiatry (in place of the Perinatal Psychiatry Special Interest Group). It is hoped that this will help to raise the profile of this area of practice within the College.

N.B. In June, Council endorsed a recommendation from the Court of Electors that the Rehabilitation and Social Psychiatry Section and the Liaison Psychiatry Section should have Faculty status. (rib AGM agenda 5)

REVIEW OF SPECIAL INTEREST GROUPS (SIGs) Council undertook a review of SIGs, and agreed that the number of SIGs should be capped at 15, and that SIGs should be required to fulfil certain requirements (such as demonstrating that they had been active during the year in order to be maintained).

Proposals to establish new Special Interest Groups in Complementary and Alternative Medicine and Social Science and Psychiatry were published in the June issue of the Bulletin. One hundred and twenty signatures from interested members are required by the end of November in order to establish these new groups.

A range of policy Working Groups including those within Faculties and Sections - are currently engaged in updating College policy statements
(Council Reports) and preparing new reports. CRs endorsed by Council recently include:

- Management of self-harm

- Covert administration of medicines

- Prescribing psychotropic drugs for patients with HIV and AIDS

- ECTHandbook

- Community Mental Health Care

- Psychiatric services for children and adolescents with a learning disability

- revised Good Psychiatric Practice guidance (which will replace CR83) this will be circulated to all members in the UK.

Other new guidance in the GPP series guidance on sponsorship (Good Psychiatric Practice: Interim guidance on the relationship between psychiatrists and commercial sponsors and the sponsorship of College activities) was published on the College's website last June, and will be updated regularly.

Revised Good Psychiatric Practice guidance on confidentiality (to replace CR85) is currently being developed.

Once published, these reports will be available in PDF format from Publications area of College's website and most will be available in hard copy for purchase from book sales office.

A small number of Scoping Groups have also been set up to explore a range of topics. These Scoping Groups are encouraged to think radically, and are expected to report to Council promptly! The following groups are in progress:

Roles and Values of Psychiatrists linking in with the 'New Ways of Working' initiative in the E\&W Department of Health

Support for College members - to support members experiencing harassment and bullying, in who may wish to seek the College's advice in making complaints

Scoping Group on the College's Constitution - Preliminary recommendations were endorsed by Council earlier this year. These focus on the devolution of a range of functions to the College Divisions, in order to enhance the role and responsibilities of Divisions and to enable members to feel much more part of the College. The Divisions will take on a range of functions currently undertaken by the College centrally.

To facilitate the Divisions to extend their functions, staffed Offices are being set up in the English Divisions. In order to minimise costs, the eight English Divisions will share five offices, as follows:

Northern \& Yorkshire/North West

Trent/West Midlands

Eastern/South East

London

South West
Work is currently taking place to identify office accommodation and recruit staff.

A new College Division has been introduced in Northern Ireland, with a staffed office in Belfast. (The former Irish Division is no longer responsible for policy matters in Northern Ireland. The two Divisions meet regularly to discuss matters of mutual interest, and a new body - the All-Ireland Institute of Psychiatry - was introduced to ensure cross-border communication and, where possible, commonality, between the two Divisions.)

A member of staff has recently been appointed to support the Welsh Division.

The Constitution Scoping Group's second report - proposing changes to central structures - is currently being finalised for consultation.

New Scoping Groups are to be introduced to explore the following areas:

Court work and Physical care of psychiatric patients.

\section{Equality and diversity}

The College has now produced a Statement of Equal Opportunities, which will be uploaded on to the equality and diversity area of the website.

Active implementation of the Race Equality Action Plan (led by Parimala Moodley) continues. A new initiative in relation in Gender Equality (led by Sheila Hollins) has now been introduced. Council has endorsed a Gender Equality Statement of Intent for the College, and will be invited to endorse the Gender Equality Project's Action Plan in the Autumn.

The results of the 2003 ethnic and gender monitoring surveys* have been reviewed by Council. Key results will be uploaded on to the equality and diversity page of the website.

\section{New consultant contract and implications for College work}

Five different contracts are being introduced across the UK, which seem to be being implemented in an inconsistent way. Negotiation with employers in respect of College work will be needed. The College is keen to hear the experiences of members. Members should write to the Chief Executive or comment via the College's new website, which will include a new 'current issues for debate' page.

\section{Postgraduate Medical Education and Training Board (PMETB)}

Introduction of PMETB - which will replace the STA - is likely to be delayed. The College has been advised that it will be invited to nominate representatives for the two main sub-committees on Training and Accreditation. 
Reform of the Mental Health Act 1983

Second draft Bill awaited... which will then proceed to the Joint Legislative Committee for scrutiny. The College would have the opportunity to present evidence to the Committee.

\section{Mental Capacity Bill}

The long awaited Mental Capacity Bill received its 1st reading in parliament on 17 June. The College welcomed the publication of the Bill, but expressed concern at some key omissions in relation to safeguards for people who lack capacity. The absence of a 'right to advocacy' for people who are unable to make decisions for themselves is particularly significant. The 2 nd reading is expected after the summer recess in September.

\section{Extended sentences}

Council recently approved a revised draft statement on the impact of extended sentencing on the ethical framework of psychiatry, prepared by the Forensic Psychiatry Faculty. Consultation will take place with the AoMRC and the WPA ethics committee on the issue. The statement will be published in the Bulletin and on the College's website, and comments will be invited from College members via the current issues page.

\section{National Institute for Clinical Excellence -}

The College has registered for round 50 NICE guideline - including those being developed in areas of mental health (mostly by the NCCMH), and those in areas of medicine and surgery where it is considered that psychological sequaelae should be considered in developing the guideline. The College is also participating in NICE Health Technology Appraisals.

\section{Report from theTreasurer - Dr Fiona Subotsky}

The Treasurer referred the audience to the summarised report available to them, and went through the main observations with some simplification and updating as appropriated.

For the year 2003, the College's income was about $f 9$ million with an expenditure of $f 8 \frac{3}{4}$ million, thus there was a surplus of about $f_{\frac{1}{4}}$ million. In addition there were improved returns from equities.

Membership subscriptions are the biggest single source of income and are likely to continue to be so. Today, I can report that Membership stands at 10998 so the figure of 11000 is nigh.

In terms of Membership categories: as the Registrar has mentioned, the new category of International Associateship has now been approved, and will be brought in soon. For Inceptors we are hoping to improve services, by a possible change of name, facilitating access and involvement, and maximising relevant benefits.

On Meetings, The Annual Meeting, held in Edinburgh, which again proved to be a successful venue, achieved a surplus of about $f 120000$ without allocation of central overheads. Meeting of Faculties and Sections generally continued to make a surplus, which both supported the Development Fund and made possible the start-up of the online CPD project.

The Examinations department once again had an increase of applicants, and achieved a moderate surplus. This enabled capital expenditure on IT for the department and development of services for trainees such as the conference day for SHOs, which it is planned to repeat. Examinations will continue to remain a focus for change, so the need for development investment will continue.

The Publications department did less well than usual, as forseen, but some areas did well especially the Journal Advances in Psychiatric Treatment.

The College Research Unit had another successful year, expanding its activities. We considered, but did not proceed to purchasing, new premises and are currently considering this again.

Other expenditure items included the completion of the Changing Minds campaign and the start of the Partners in Care campaign, run in conjunction with the Princess Royal Trust for Carers. The beginnings of more devolved activities included the setting up of an office in Northern Ireland. To continue this devolutionary restructuring a relative increase in subscriptions is necessary.

Finally I would like to thank the Chief Executive, Vanessa Cameron and Paul Taylor, Head of Financial Services, and their staff, for all their hard work and support throughout the year.

\section{To consider Resolutions, if any}

No resolutions had been received for discussion at the meeting.

This concluded the business meeting, which was followed by the presentations. The Registrar presented to the President representatives from overseas psychiatric organisations, then College Prizewinners and New Fellows. Following this the Registrar called upon the Citators of each Honorary Fellow for 2003 to come forward and give their citation, as follows.

\section{HRH The Princess Royal}

(The citation was given by Dr Mike Shooter)

Your Royal Highness, Ladies and Gentlemen

Many more years ago than I care to remember, when I was still a callow senior registrar in child psychiatry, I went to visit a hospice in Stirling, Strathclyde. I did so because I had a special interest in working with children who have chronic physical illness, and therefore, regretfully, with death and bereavement in families. I was running a training workshop for the hospice staff.

Just before it was due to start, I learnt that the hospice was to have a Royal visitor later in the day but that I wasn't to worry because it was The Princess Royal, their patron. She was a working patron, they said, who was there to do business. She wanted no fuss. She would fit her business round the hospice programme. That, I thought, is the sort of person I would like to be involved with anything I was in charge of - and here we are!

Her Royal Highness has many public faces. In her ceremonial capacity, she is the seventh holder of the title, The Princess Royal. In 1987, The Princess Royal was made a Fellow of the Royal Society and in 1994 the Queen appointed her a Knight of the Most Noble Order of the Garter. In 2000, to mark her 50th birthday, The Princess Royal was appointed to the Order of the Thistle. The Princess carries out up to three overseas tours each year for the Foreign and Commonwealth Office, in support of British interests, and a wide range of official duties within the United Kingdom.

For many of the public, if the Princess will forgive me for saying so, she will be forever pictured riding a horse - or, occasionally, falling off it! From her early childhood, riding has been the Princess's greatest passion. She regularly competed in the Horse of the Year Show at Wembley and in the Badminton Horse Trials. In September 1971, The Princess won the individual, European, Three Day Event at Burghley and was nominated Sportswoman of the Year by that holy triumvirate - The Sports Writers' Association, the Daily Express newspaper, and World Sport (the Journal of the British Olympic Association). In 1971, the Princess was voted BBC's Sports Personality of the Year.

In 1973, the Princess was a member of the British team in the European Three Day Event championships in Kiev. Two years later, she won both individual and team silver medals in Germany. The Princess competed in the 1976 Montreal Olympics and became President of the British Olympic Association in 1983. In 1988, she became one of the two United Kingdom members of the International Olympic Committee and has been an enthusiastic supporter of every Olympics in the last 20 years. She was there at the climax of the celebrations as the Olympic torch passed through London 2 weeks ago. As a horse-racing fanatic who has spent many Saturdays backing horses but never ridden one, I would of course expect her advice when I finally persuade the Treasurer that we could make more 
money for the College of Cheltenham than our investment portfolio!

But it is for the Princess's life-long support of charities and health care organisations that this citation is offered to you. The Princess Royal is President, Patron or Chancellor of some 222 different bodies - including Riding for the Disabled, Save the Children, the Queen Victoria Hospital NHS Trust, London University, the Royal Colleges of Midwives, Anaesthetists and Paediatrics and Child Health. The Princess has been instrumental in the foundation of many charities. Transaid, Riders for Health, and most notably the Princess Royal Trust for Carers.

I have been wonderfully cared-for in my own episodes of illness and was determined that carers would in some way be championed if ever I became President. I began accepting invitations to speak at carers' meetings around the country (usually at football stadia). Many of these were held under the auspices of the Princess Royal Trust for carers and I had a chance to meet Her Royal Highness and watch her at first hand. Three things struck me every time - her sheer hard work on behalf of any organisation to which the Princess had dedicated herself, her unwillingness to stand on any sort of ceremony, and her approachability. I saw her shake hands with scores of people and remember every one of their names, from past meeting, and without prompt. In other words, it confirmed everything had heard all those years ago in Stirling.

We were delighted that The Princess Royal Trust for Carers and the College have come together in this year's campaign: 'Partners in Care'. We were even more delighted that Her Royal Highness agreed to launch the Campaign back in London, in January, and to speak halfway through it, here in Harrogate at our AGM. We are honoured that The Princess Royal has agreed, in recognition of her work, to accept the highest honour that our College can give to world leaders, academics, and fellow clinicians - the Honorary Fellowship.

Ladies and Gentlemen, I wholeheartedly commend to you someone who works tirelessly for causes close to our hearts. She would undoubtedly be the only College Fellow to have done two things all of us would have wanted to do - have represented her country at the Olympics and hand-bagged Emlyn Hughes on a Question of Sport!

\section{Lord Bragg}

(The citation was given by Professor Cornelius Katona)

Melvyn Bragg was born in 1939 in Wigton, Cumbria. He won a scholarship to Wadham College Oxford, where he read history. He joined the $B B C$ as a general trainee in 1961. Three years later, he was appointed editor of BBC2's first arts programme, First Release. Since then, has become the pre-eminent figure in arts broadcasting

As editor and presenter of The South Bank Show, and as Controller of Arts for London Weekend Television, Melvyn Bragg is well known for his promotion of literature and the creative and performing arts. He is equally respected for his contribution to the public awareness of basic and social sciences and of philosophy. He has chaired The Darwin Debate on BBC2, which looked at the significance of evolution theory for human society and the Radio 4 series on the history of science, On Giants' Shoulders. He has also presented a 20-part history of Christianity on ITV. His recent The Routes of English and In Our Time projects are likewise testimony to his range.

Melvyn Bragg has also achieved both popular and critical success as a writer, again with a surprising breadth of output. As well as several screenplays, he has written 17 novels, one of the most recent of which, The Soldier's Return, won the W H Smith Literary Award for 2000. He has also written a biography of Richard Burton. His novel, Crossing the Lines, was published last year, as was The Adventure of English 500AD-2000AD, a revised account of his widely acclaimed ITV series about the English language.

He has been President of the National Campaign for the Arts since 1986, and a Governor of the London School of Economics since 1997. He has honorary degrees from the Universities of Wales, Liverpool, Lancaster, Leeds, SouthBank, St Andrews, Northumbria, Brunel, Northumbria, UMIST and the Open University. He was made a Life Peer in 1998, becoming Lorg Bragg of Wigton in the County of Cumbria. He was elected Chancellor of Leeds University in 1999.

It is not only for these extraordinary achievements that we are honouring Lord Bragg. He has, as we psychiatrists put it, a long history of commitment to the cause of mental health, stemming back to his own experience of mental illness in his teenage years, which he has discussed publicly with exemplary bravery. In his own words, 'The experience were terrifying. I could literally feel a part of me leaving and hovering above my body.' As a result, he has become one of the country's most powerful advocates for people with a mental illness. In his own words 'I saw people with mental distress being outcast and stigmatised and misunderstood'.

Lord Bragg has been involved with MIND in Carlisle for 16 years and in 2001 became national President of that organisation. He is now committed to campaigning on mental health issues within the House of Lords. In these troubled times Lord Bragg is a true friend to psychiatry and to the College. Would that we had more friends like him!

On a more exalted note, Lord Bragg is one of that very select band of intellectuals who can lay claim to the Renaissance ideal of the 'uorno universale'. For this as well as for his commitment to the cause of mental health it is both a privilege and a personal pleasure for me to present him for the College's highest honour, the Honorary Fellowship.

\section{DrAbraham Halpern}

(The citation was given by Professor Pamela Taylor)

Abraham - Abe - Halpern is a world citizen. He is firmly anchored in North America, having trained in Canada and practised in the USA, but his concern for others, and his actions for others are spread much more widely than that.

Abe is Professor Emeritus of Psychiatry of New York Medical College, in the improbably and wonderfully named Valhalla district of New York. Those of us who, now and again, disappear for a week's leave in an opera house are not surprised that such a place delivers us a hero.

He has practised across a range of fields in psychiatry and still does - now in private practice even though America is a less ageist society than the UK. His particular interests have been in forensic psychiatry, and he was, through the early 1980s, Director of the American Board of Forensic Psychiatry. His expertise has, however, also put him in demand for other specialist areas.

He has not only done sterling work directly with patients, and been a stalwart of many committees, learned and professional associations, but he has also been responsible for setting up key bodies and divisions of wider organisations such that practitioners are sure to have access to the kind of peer reference and suppor that are so important if we are to be effective in our working lives. Such efforts have been within the familiar territory of the psychiatric profession, and within the challenging fields of prison medical services and medical jurisprudence.

For example, he has served on a number of specialist committees and task forces of the American Psychiatric Association - a body ahead of us in honouring him - and for a range of other medical, psychiatric and medico-legal societies. He has been President of the American Academy of Psychiatry and the Law, and held many other offices within that organisation besides, also being instrumental in setting up its Eastern Seaboard Tristate Chapter. His extensive knowledge and sound judgement in ethical matters have brought him not only a range of more 
obvious jobs, such as membership of the Medical Malpractice Panel of the New York Supreme Court, but he has also been sought after outside his more regular sphere. He was, for example, a member of the ethics review board for the in vitro fertilisation Australia Program at the United Hospital Medical Centre through the late 1980s and the early 1990s. To this day, he serves on the International Council of Prison Medical Services.

His influence extends way beyond such committees too, in that he has over 200 publications to his name, and has been much sought after as editor, or member of editorial boards for a number of professional journals. Indeed, the American College of Physicians has just presented him with the Menninger Memorial Award for distinguished contributions to the science of mental health.

This is all magnificent stuff, for which he has been justly honoured within his own country, but why should we add to the growing pile of honours from this side of the pond?

Thirty-eight states of the USA and the US federal government engage in what we in Europe refer to as 'a cruel and unusual punishment'. In company with some of their sworn enemies and some countries which they regard as, at best 'developing' and at worst corrupt, all but 12 states of the USA still engage in premeditated killing endorsed by their judiciary. True the victims of this state endorsed homicide have generally been convicted of killing someone else, but the philosophy behind such a sentence is founded in a pre-christian religious fundamentalism that seems at odds with a society which otherwise seems so advanced, and, in some circumstances is capable of the most generous humanitarian acts. Abe, often accompanied by another American Psychiatric luminary, Alfred Freedman, has campaigned vigorously against the death penalty. He has been emphatic about ensuring that the medical profession in the USA would regard their participation as wholly unethical. He has persuaded a number of bodies to make this explicit in their professional codes. Physicians nevertheless remain vulnerable to the dilemma of whether or not to treat people who are on death row but also seriously mentally ill. The next battle is to establish restriction of their role in this, but, even more importantly, to get each of the leading clinical professional bodies to call explicitly for the abolition of the death penalty in the USA. As an aside, where Abe Halpern leads, the Pope follows - he too is now calling for abolition of the death penalty.

So, $\mathrm{Dr}$ Halpern is seeking to set his own country straight, and that puts him in a better position than most for seeking change in other countries too. He prepared the ground for our profession's actions in Russia, with the end result of substantial benefits for our Russian colleagues as well as their patients. He has now extended his concerns about the potential for state abuse of psychiatry to the People's Republic of China. Indeed, such was Abe's reputation as a righter of wrongs, that, almost immediately after the terrible events in Tiananmen Square, Falun Gong practitioners beat a path to his door with evidence that some of their members were being detained as psychiatric patients, and treated with powerful medications, in the absence of mental disorder. He took up their case, and that of other Chinese dissidents too, and persuaded the WPA to require of the Chinese government that they allow independent inspections of psychiatric hospitals in China. There is still a long way to go in achieving this, and to relief for subjected people and psychiatric practitioners alike from such misuses, but the first important step of world awareness has been taken, thanks in large part to Abe.

In the Royal College of Psychiatrists we are just the latest in a long line of bodies recognising Abe's achievements. It is impossible in the time to list them all, but I have been astonished by the range from service awards, through honours for commitment to a range of learned bodies, to the rights, citizenship and humanitarian awards that mark you out as so exceptional. I am impressed that, among them, Abe has also had the time and ability to pick up a Sigmund Freud award from the American Society of Psychoanalytic Physicians, - and in the nicest possible way slightly envious of awards I hardly understand but with titles that are so enticing - the Liberty Bell Award of one County Bar Association, the Golden Apple award of the American Academy of Psychiatry and the Law. They have a more romantic ring than the sort of titles we aspire to in this country, and yet, the Honorary Fellowship of our College is its highest accolade, and what could be better than the concept of joining in Fellowship. With this award we seek to honour Abe Halpern's achievements, but the nature of fellowship is such that in accepting it, he will also be honouring us.

\section{Professor Philip Graham}

(The citation was given by Professor Sir Michael Rutter)

It gives me the greatest pleasure to present Philip Graham as a most distinguished recipient of an Honorary Fellowship in the Royal College of Psychiatrists - the highest honour that the College bestows. Philip was born in 1932. After leaving school he attended the Sorbonne in Paris before going on to receive his medical education at
Cambridge University and then University College London, graduating in 1960.

Throughout this period he participated in various acting groups, and his acting accomplishments (including acting as Gertrude to Peter Hall's Hamlet while at school) have perhaps made it easier for him to hold the stage so well on psychiatry big occasions

My task today is made difficult by the need for choice in the huge range of Philip's accomplishments that I could discuss. So let me start personally, by recalling the time more than 4 decades ago when Sir Aubrey Lewis - a tough and demanding leader but an astute judge of people - drew my attention to Philip's brilliant qualities (then as a trainee) and strongly recommended him as just the sort of person needed to provide leadership in academic child psychiatry. I quickly appreciated that Lewis was correct in his judgment and there followed a wonderful period during which Philip and I collaborated closely together - most notably in the Isle of Wight studies, the success of which owed much to Philip's combination of excellent strategic vision, innovative ideas on methods, immense capacity for hard work, appropriate attention to crucial detail, good working relationships with colleagues (both junior and senior) and a sense of fun and good humour that did much to make the whole enterprise so enjoyable.

He went on, in his research, to establish with Naomi Richman and Jim Stevenson the Waltham Forest epidemiological study. This was particularly important in demonstrating for the first time the prognostic importance of psychopathology in the pre-school years, and in its identification of crucial risk factors in individuals and their families. The close integration of clinical and epidemiological skills, together with a firm commitment to using research findings to improve the planning of services and to inform policy decisions, constituted the hallmark of not only those early pioneering studies, but all those that followed during subsequent years.

However, Philip's contributions extend way beyond his empirical research, highquality though that has been, I would like to single out three main features that have made him stand out as unusually distinguished, even within a group of stellar academics. First, he is a firmly committed internationalist with a particular interest in helping colleagues in developing countries develop first rate services that build on what has been achieved elsewhere but which are sensitively adapted to their own particular circumstances and needs. On the world scene he has been a uniquely valuable advisor and consultant to the World Health Organization over many years and he was instrumental in establishing the interdisciplinary Diploma in Child and 
Adolescent Psychiatry, run jointly between the Institutes of Child Health and of Psychiatry, with a primary focus on those from developing countries. In addition, more than any other child psychiatrist, he has fostered cooperation and collaboration across Europe, strengthening academic standards and research-clinical links. This was recognised in his being elected president of the European Society of Child and Adolescent Psychiatry from 1987 to 1991 and his holding of a parttime chair at the University of Oslo during the 1990s.

Second, from the outset, Philip has championed interdisciplinary collaboration but, throughout, he has never held back from constructive criticism and provocative comments when those have been needed. By nature, he dislikes pomposity and grandeur and, whilst always working for harmony and consensus, he often pokes fun at both the abuse of power and the pressing of personal agendas. That he does this within the context of recognition of other people's strengths, combined with wit, has meant that he always earns the respect of all those with whom he works. He played a major role in shaping the influential recommendations of the Warnock Committee on the Education of Children with Special Educational Needs, worked closely with the Department of Health in various roles over a period of two decades, has sought successfully to strengthen links between child psychiatry and paediatrics both in the British Paediatric Association (as it was before it became a Royal College) and at the Institute of Child Health, where he served as Dean during the 1980s. As is obvious from the many calls on his time, he is an excellent committee member thorough in his presentation, incisive and articulate in his contributions, broad and wise in his approach, not afraid to take difficult decisions when these are called for, and totally dedicated to making research findings useful in improving policy and practice. From 1994 to 2000 he was chairman of the National Children's Bureau during a period of considerable growth and he played a key role in strengthening its programmes.

Finally, Philip is an outstanding teacher and mentor to junior colleagues personally supportive but challenging and questioning when that has seemed to be what is needed. He is a knowledgeable and discriminating scholar, well aware and understanding of scientific advances, but he quite enjoys being a bit iconoclastic and critical of the supposed wisdom of the day. His balance of judgment and cohesive grasp of the big issues is clearly evident in his textbook Child Psychiatry. A Developmental Approach, now in its third edition. Doubtless, too, it will be apparent in his new book on adolescence - just published today.
It is now about a decade since Philip supposedly retired, but it is obvious that he remains extremely active and is much in demand. As I have tried to indicate, he has numerous achievements but, for me, he is most of all a superlatively good ambassador for psychiatry throughout the world and across a diverse range of disciplines. Never afraid to tackle controversial issues, he is nevertheless an indefatigable worker for harmony and successful collaboration. His election as an Honorary Fellow brings honour to the College, as well as marking our respect for what he has achieved.

\section{Professor Genevra Richardson}

(The citation was given by Professor Nigel Eastman)

At the outset of presenting Professor Genevra Richardson to you, I want to say that I cannot think of an academic lawyer more worthy of election to an Honorary Fellowship of the College. And it gives me enormous personal pleasure to be able to speak about her to you for a few minutes.

There cannot be a psychiatrist in the land who does not know the name Genevra Richardson. Where many will have known her before the present Government began its, by now tortuous, process of mental health law reform, today every psychiatrist must feel that they know her, and almost all with affec tion. The Richardson Report, often known as 'The Blue Paper', deliberately so nicknamed in order to distinguish it from the Government's own massively unpopular Green and White Papers for a new Mental Health Act, proposed law reform which would, if enacted, have made an extraordinary and huge contribution to truly modernising mental health law. Her Committee, appointed by the government to advise on a new Act, took the then Secretary of State for Health at his word when he asked for 'root and branch' reform of mental health law. Armed with both broad and deep knowledge of relevant law, and much experience of the regulation of mental and other health services, she went 'beyond' law and, introduced into public debate, ethical questions relevant to law, in a way that, with far more time and resources, her only recent 'predecessor' Lord Percy in the 1950's had not sought to do. Given an absurdly short timetable, she propoosed law reform that was, indeed, 'root and branch' in nature, seeking to bring a new Mental Health Act much closer to the common law which regulates all medical practice, including psychiatric practice which occurs outside of the ambit of such a statute. The government was literally 'petrified' by such a carefully and elegantly argued report. The ethics and internal legal logic of it were hard to resist. The strength of argument clearly posed an enormous problem for politicians who had an eye on the popular press, and its obsession with stigmatising mental illness and with public risk. Indeed, the politicians clearly could not find a way rationally, or ethically, to do deal with the Richardson Report. Hence, the government delayed publication of the 'Blue Paper' for six months in order to attempt to marginalise the report of its own appointed committee, and to give time hurriedly to 'cobble together' its own Green Paper. They then published the Green and Blue papers together. But perhaps one important result of the quality of legal and ethical argument which 'was' the Richardson Report was that it forced the government 'into the open' politically. Within the Green Paper, a document widely recognised as incapable of being drafted into statute, so ill considered was it, the government openly asserted 'what we are ultimately interested in is not health but risk, and public risk'. And yet, if they had been more 'canny', the government would have seen that, almost certainly restraining her own views that a new Act should be brought even closer to the rest of medical law than she and her committee were proposing. Professor Richardson had tempered her recommendations with 'political reality'. They were not canny, Genevra Richardson was.

The drawing together of virtually every national body with an interest in mental health services into the Mental Health Alliance represented a reaction to stigmatising and unethical government proposals. And the Richardson Report can properly be seen as the Alliance's ethical and legal rallying point and blueprint.

Professor Richardson has been, since 1994, Professor of Public Law at Queen Mary College in the University of London. She was, between 1996-1999, Dean of the Faculty of Law there, and previously held a Readership and Lectureship at the College. Prior to these appointments she worked as a researcher at the Centre for Socio-legal Studies at Oxford University. Clearly her interest in social and ethical perspectives on law, rather than just on law per se, is longstanding.

Prior to her newfound fame with psychiatrists, Professor Richardson was already an academic lawyer with longstanding expertise in mental health law who had both a national and international reputation in the field. She was certainly already recognised as the most distinguished academic mental health lawyer in this country, her only real 'competitor' having recently been appointed to the High Court bench and then the Court of Appeal! And she had combined over many years, her theoretical expertise with practical application. She was, for 
example, a member of the Mental Health Act Commission for some years, also the Mental Health Foundation, and had also chaired a major homicide inquiry. And it was clearly such prominence that decided the government that she was the obvious candidate to conduct its review of mental health legislation. They were right! But if you appoint the best, you get the best results, and that, as I have already suggested, is embarrassing if you don't like the results.

Unsurprisingly, Professor Richardson's expertise and reputation have resulted in her being invited to spend time in other countries considering issues concerning law and mental health elsewhere than in England and Wales, including Latvia!

There is inadequate time to tell you much that demonstrates that Genevra Richardson's contribution to 'things medical and scientific' is by no means limited to mental health care. She is currently a Member of Council of the MRC, Chair of Stem Cell Bank Working Group, a member of Steering Committee of the UK Stern Cell Bank, and chair of the Committee on the Ethics of Research Involving Human Participants or Tissues and Personal Information. She is also a member of the Animal Procedures Committee of the Home Office, which advises the Home Secretary on vertebrate experimentation policy, including being a member of the Subcommittee on genetic modification. She is also a Member of the Council on Tribunals, which is a little different from being a member of a Mental Health Review Tribunal! And so much more... and that is to leave out her 'proper job', her 'day job', within which she teaches and publishes widely and with much distinction within public law, criminal law, and, of course, mental health law. Professor Richardson's work specifically in mental health has always been pursued with a deep understanding of the practical issues facing mental health users, carers and practitioners, and her recommendations to the Government on mental health law reform clearly reflected this. since publication of the Government's
Green Paper (followed by the White Paper and Draft Bill) Professor Richardson has remained an active and sought after contributor to the debate about mental health law reform, often offering a robust critique of much that is proposed by the Government. It is not a matter of gamekeeper turned poacher; she was never either. Quite simply she acted with enormous integrity and dignity during her time advising the Government, often in the face of behaviour from others which did not always come up to her own very high standards. And, when the politics moved on, and the ethical and legal heart of her Committee's proposals had been rejected by the government, she 'spoke her own mind', but again always with care and dignity

\section{Vote of Thanks}

The Vote of Thanks on behalf of the Honorary Fellows for 2004 was given by Lord Bragg. 